\title{
KOMPETENSI GURU ALUMNI JURUSAN PENDIDIKAN MATEMATIKA BERDASARKAN PENDAPAT PENGGUNA LULUSAN
}

\author{
Melda Jaya \\ Dylmoon Hidayat \\ Hastuti Pakpahan \\ Universitas Pelita Harapan, Tangerang - Banten \\ melda_alin@yahoo.co.id
}

\begin{abstract}
ABSTRAK
Undang-Undang Sistem Pendidikan Indonesia No.20 tahun 2003 pasal 35 menyatakan bahwa kompetensi lulusan harus ditingkatkan secara berencana dan berkala. Dalam rangka peningkatan tersebut perlu diketahui kompetensi lulusan untuk program perbaikan secara menyeluruh. Para lulusan Fakultas Ilmu Pendidikan Teachers College Program Studi Pendidikan Matematika Universitas Pelita Harapan tersebar di seluruh wilayah Indonesia baik di sekolah-sekolah yang berada di dalam maupun di luar Yayasan Pendidikan Pelita Harapan. Semasa kuliah, mereka telah dibekali dengan berbagai kemampuan untuk mendukung profesionalisme mereka sebagai guru. Penelitian ini bertujuan untuk mengetahui dampak guru-guru lulusan FIP Teachers College Program Studi Pendidikan Matematika UPH bagi sekolah-sekolah tempat mereka mengajar, sebagai bahan masukan untuk perbaikan kedepan yang lebih baik. Penelitian ini dilakukan dengan metode survei. Subjek penelitian ini adalah para kepala sekolah, CC/TT dan peserta didik. Hasil penelitian ini diharapkan dapat memberikan evaluasi bagi usaha peningkatan kompetensi lulusan FIP Teachers College Program Studi Pendidikan Matematika UPH. Dari hasil penelitian diperoleh kesimpulan bahwa secara umum alumni pendidikan matematika Teacher College berdasarkan pengguna lulusan sudah mencapai ke empat kompetensi berdasarkan graduate profile Teacher College, antara lain: Guru bidang studi matematika Kristen, Guru bidang studi matematika dengan standar internasional, Seorang Kristen yang dewasa, Seorang anggota komunitas yang signifikan, namun ada beberapa aspek didalamnya yang perlu ditingkatkan dan diperbaiki.
\end{abstract}

\section{Kata Kunci: Kompentensi Lulusan, Pengguna Lulusan}

\section{PENDAHULUAN}

Allah menciptakan manusia segambar dan seturut rupa Allah (Kejadian 1:26). Allah membekali manusia dengan akal budi, sehinga manusia bisa membedakan mana yang baik dan benar, manusia mampu untuk berpikir, sesuai dengan kehendaknya Allah. Allah juga memberikan manusia mandat menadi rekan sekerja Allah untuk memelihara dan mengembangkan bumi dan mengusahainya. Hasil pemikiran manusia terus berkembang dalam dunia pendidikan. Pendidikan tersebut diselenggarakan baik oleh masyarakat maupun pemerintah. Pemerintah Indonesia melalui Kemendikbud mengupayakan penyelenggaraan pendidikan di Indonesia dalam berbagai jenis dan tingkatan pendidikan. Dari setiap upaya penyelengaraan dan pengembangan pendidikan yang dilakukan pemerintah memiliki dasar dan tujuan dari setiap jenis dan jenang pendidikan termasuk perguruan tinggi. Pendidikan tinggi bertujuan untuk mempersiapkan peserta didik menjadi sumber daya yang menguasai cabang ilmu pengetahuan/teknologi untuk memenuhi kepentingan nasional dan daya saing bangsa (Dalam UU No. 12 Tahun 2012 pasal 5). Sehingga setiap penyelenggara pendidikan tinggi 
sangat perlu melihat kompetensi lulusannya, karena tingkat keberhasilan dari suatu lembaga pendidikan dapat dilihat dari kompetensi lulusan.

Lembaga pendidikan tenaga kependidikan sebagai bagian dari perguruan tinggi diharapkan dapat menghasilkan calon pendidik profesional sebagai penyelenggara pendidikan yang memiliki kompetensi sesuai dengan kebutuhan masyarakat. Undang-Undang Sisdiknas No.20 tahun 2003 pasal 35 menyatakan bahwa kompetensi lulusan harus ditingkatkan secara berencana dan berkala. Kompetensi lulusan harus memiliki standar. Standar Kompetensi Lulusan adalah kriteria mengenai kualifikasi kemampuan lulusan yang mencakup sikap, pengetahuan, dan keterampilan (PP No.32 Tahun 2013). Untuk mencapai peningkatan yang berencana berkelanjutan akan kompetensi lulusan perguruan tinggi, maka stakeholders dalam lembaga pendidikan tinggi yang dalam hal ini BAN-PT juga menuntut untuk melaporkan hal tersebut dalam mereorganisasi dan meningkatkan kualitas layanan kepada publik.

Sejalan dengan perkembangan ilmu dan teknologi serta dinamika masyarakat yang tidak pernah berhenti, lulusan pendidikan tinggi dituntut memiliki kemampuan beradaptasi, kemampuan berkomunikasi, kemampuan bekerja sama, jujur, inovatif, dan mempunyai komitmen yang tinggi terhadap pekerjaannya. Pendidikan tinggi mempunyai kewajiban dan tanggung jawab terbesar dalam membangun fondasi daya saing bangsa dengan menghasilkan sumber daya manusia yang bertakwa, cerdas, kreatif, profesional, dan produktif; menghasilkan temuan dan inovasi baru melalui penelitian-penelitiannya; serta mengkapitalisasikan ilmu pengetahuan, teknologi, dan seni untuk meningkatkan kemandirian dan kesejahteraan bangsa melalui pengabdiannya kepada masyarakat (Direktorat Jenderal Pendidikan Tinggi, 2009 : 1).

Sejalan dengan hal tersebut, Lembaga Pendidikan Tenaga Kependidikan sebagai bagian dari perguruan tinggi diharapkan dapat menyediakan lulusan calon-calon guru yang kompeten di bidangnya sesuai dengan kebutuhan masyarakat yang ada, sehingga perlu memperhatikan kebutuhan masyarakat, kepentingan pengguna dan memperoleh masukan dari pengguna untuk perbaikan yang lebih baik. Setiap perguruan tinggi diharapkan perlu berpacu kepada hal tersebut diatas, termasuk Fakultas Ilmu Pendidikan Teachers College.

Fakultas Ilmu Pendidikan Teachers College Program Studi Pendidikan Matematika Universitas Pelita Harapan telah berdiri sejak tahun 2009 dan telah menghasilkan lima angkatan lulusan sampai dengan tahun 2014. Para lulusan ini tersebar di seluruh wilayah Indonesia baik di sekolah-sekolah yang berada di dalam maupun di luar Yayasan Pendidikan Pelita Harapan.

Semasa kuliah, mereka telah dibekali dengan berbagai kemampuan untuk mendukung profesionalisme mereka sebagai guru khususnya sebagai guru Kristen yang dewasa. Menurut Van Brummelen (1998), seorang guru Kristen bertindak sebagai pelayan, imam dan penuntun bagi peserta didik. Para Lulusan Program Studi Pendidikan Matematika diharapkan dapat berlaku sebagai seorang Kristen yang dewasa, seorang guru Kristen bidang studi Pendidikan Matematika, seorang guru dengan standar internasional, dan seorang anggota komunitas yang signifikan.

Sebagai seorang Kristen yang dewasa, lulusan Program Studi Pendidikan Matematika diharapkan memiliki pikiran, tindakan dan perkataan berdasarkan sudut pandang Kristen. Ini merupakan bentuk manifestasi dari kepastian akan keselamatan dalam Kristus, dan hubungan pribadi dengan Bapa, Anak dan Roh Kudus. Mereka diharapkan mampu mempertahankan kebenaran iman Kristen di tengah pandangan-pandangan dunia dan memiliki hati yang terbeban untuk memberikan yang terbaik.

Sebagai guru Kristen bidang studi Pendidikan Matematika, lulusan Program Studi Pendidikan Matematika diharapkan dapat melihat perannya sebagai bentuk pelayanan Kristus bagi dunia. Mereka diharapkan memiliki pengetahuan yang luas dalam bidang studi Matematika dan pendidikan yang berdasarkan pada pandangan iman Kristen; memiliki sikap dan tindakan 
yang semakin menyerupai Kristus untuk menolong peserta didik bertumbuh dalam pengetahuan, ketrampilan, sikap dan karakter mereka yang benar.

Sebagai guru dengan standar internasional, lulusan Program Studi Pendidikan Matematika diharapkan memiliki pemahaman integratif tentang cara peserta didik dalam belajar; kepekaan akan aspek spiritual, emosional, sosial, intelektual dan fisik karakteristik peserta didik; kemampuan mengembangkan kurikulum; penguasaan teori belajar dan prinsip pendidikan serta kompetensi mata pelajaran yang diampu. Program Studi Pendidikan Matematika mengacu pada Universitas-universitas Luar Negeri seperti Corban University sebagai Standar Internasional.

Sebagai seorang anggota komunitas yang signifikan, lulusan Program Studi Pendidikan Matematika diharapakan dapat membina relasi yang baik dengan masyarakat. Mereka dapat beradaptasi di tempat bertugas di seluruh wilayah Republik Indonesia yang beragam serta membangun komunitas berdasarkan anugrah, kedamaian, pengharapan, kasih.

Tujuan penelitian adalah untuk melihat dan menelaah bagaimana kompetensi guru alumni pendidikan matematika Teachers College berdasarkan pengguna lulusan. Bagi Program studi Pendidikan Matematika UPH Teachers College sendiri, tracer study bermanfaat sebagai masukan/ informasi penting untuk pengembangan di jurusan pendidikan matematika, baik kurikulum dan pengembangan kualitas dosen, staff. Bagi sekolah-sekolah hasil penelitian ini menjadi bahan masukan dalam menyiapkan diri untuk menyediakan pelatihan-pelatihan yang relevan bagi guru-guru.

\section{TINJAUAN PUSTAKA}

\section{Kompetensi Guru}

Jhonson menyatakan:" Competency as rational performance which satisfactorily meets the objective for a desired condition" (Charles E Johnson,1974 dalam Sanjaya 2006). Kompetensi merupakan perilaku rasional guna mencapai tujuan yang dipersyaratkan sesuai dengan kondisi yang diharapkan. Dengan demikian, suatu kompetensi ditujukan oleh penampilan atau unjuk kerja yang dapat dipertanggungjawabkan (rasional) dalam upaya mencapai suatu tujuan. Sebagai profesi ada beberapa kompetensi yang dimiliki oleh seorang guru, yaitu kompetensi pribadi, kompetensi profesional, dan kompetensi sosial kemasyarakatan.

\section{Kompetensi Guru Alumni Jurusan Pendidikan Matematika Teachers College}

Berdasarkan graduate profile Jurusan Pendidikan Matematika Teachers College, (College, 2015 : hal 11) kompetensi yang harus dimiliki seorang guru Kristen terdiri dari 4 yaitu:

a. Seorang Kristen yang dewasa, dimana lulusan Program Studi Pendidikan Matematika akan membentuk semua pikiran, tindakan dan perkataan dari sudut pandang Kristen sebagai manifestasi dari kepastian akan keselamatan dalam Kristus, dan hubungan pribadi dengan Bapa, Anak dan Roh Kudus sehingga sehingga mampu mempertahankan kebenaran iman Kristen di tengah pandangan-pandangan dunia. Memiliki hati yang terbeban untuk memberikan yang terbaik bagi orang lain yang termediasi oleh visi dan misiNya.

b. Guru bidang studi matematika Kristen, yaitu seorang guru yang melihat perannya sebagai pelayan Kristus bagi dunia, memiliki wawasan dan pengetahuan yang luas dalam bidang studi matematika berdasarkan perspektif Kristen, memiliki sikap dan tindakan yang semakin menyerupai Kristus, serta menolong siswa-siswa bertumbuh dalam pengetahuan, ketrampilan, sikap dan karakter mereka yang sesuai dengan pandangan hidup Kristen.

c. Guru bidang studi matematika dengan standar internasional, yaitu guru yang memiliki pemahaman tentang peserta didik dalam berpikir, bertumbuh dan belajar; Menguasai dan memiliki kepekaan terhadap karakteristik peserta didik dalam aspek spiritual, emosional, 
sosial, intelektual dan fisik; Mengembangkan kurikulum berdasarkan prinsip-prinsip Alkitabiah; Menguasai teori belajar dan prinsip pendidikan serta menguasai standar kompetensi dan kompetensi dasar mata pelajaran yang diampu.

d. Seorang anggota komunitas yang signifikan, dengan cara membina relasi yang baik dengan masyarakat, beradaptasi di tempat bertugas di seluruh wilayah Republik Indonesia yang memiliki keragaman iman, sosial, dan budaya serta membangun komunitas berdasarkan anugerah, kedamaian, pengharapan, kasih.

\section{Pengguna Lulusan}

Yang dimaksudkan pendapat pengguna lulusan dalam hal ini adalah pendapat/penilaian dari pemangku jabatan dari guru alumni seperti kepala sekolah, wakil kepala sekolah, CC/TT (Curriculum Coordinator/ Teachers Trainer).

Dari penjelasan tersebut diatas, kompetensi Guru Alumni Jurusan Pendidikan Matematika Teachers College, didasarkan semua pada graduate profile Jurusan Pendidikan Matematika Teachers College dan kompetensi yang dibutuhkan untuk menjadi guru seorang guru di sekolah-sekolah yayasan Pelita Harapan.

\section{METODE PENELITIAN}

Metode yang akan digunakan dalam penelitian ini adalah metode survei khususnya jenis cross-sectional survey, (Arikunto, 2010), dengan teknik pengambilan sampel secara serentak terhadap lulusan Program Studi Pendidikan Matematika yang tersebar di beberapa sekolah di berbagai daerah. Subjek penelitian ini adalah para kepala sekolah, CC/TT (Curriculum coordinator/Teachers Trainer). Instrumen utama dalam penelitian ini adalah angket, setelah terlebih dahulu divalidasi. Dalam angket tersebut juga diberikan kolom keterangan sebagai ruang untuk mengemukakan pendapat pengguna pada setiap butir angketnya, sehingga ada informasi tambahan sebagai bahan masukan atau keterangan tambahan dari pengguna.

Adapun tafsiran keberhasilan setiap indikator digambarkan dalam tabel berikut (Alma, B. 2009):

Tabel 1: Tafsiran keberhasilan

\begin{tabular}{ccc}
\hline No & Persentasi Baik dan Sangat baik (\%) & Kategori \\
\hline 1 & $81-100$ & Sangat Kuat \\
2 & $61-80$ & Kuat \\
3 & $41-60$ & Cukup \\
4 & $21-40$ & Lemah \\
5 & $0-20$ & Sangat Lemah \\
\hline
\end{tabular}

\section{HASIL DAN PEMBAHASAN}

Berikut ini digambarkan data yang diperoleh dari penelitian pendapat pengguna terhadap lulusan Program Studi Pendidikan Matematika:

\section{Seorang Kristen Yang Dewasa}

Dari hasil yang penelitian kompetensi ini tercapai $71 \%$ tergolong kategori baik dan sangat baik. Hal ini menunjukkan lulusan Program Studi Pendidikan Matematika dalam kompetensi ini kuat, artinya secara umum pencapaian lulusan sudah baik dalam membentuk semua pikiran, tindakan dan perkataan dari sudut pandang Kristen sebagai manifestasi dari kepastian akan keselamatan dalam Kristus, dan hubungan pribadi dengan Bapa, Anak dan Roh Kudus sehingga sehingga mampu mempertahankan kebenaran iman Kristen di tengah 
pandangan-pandangan dunia, Memiliki hati yang terbeban untuk memberikan yang terbaik bagi orang lain yang termediasi oleh visi dan misiNya.

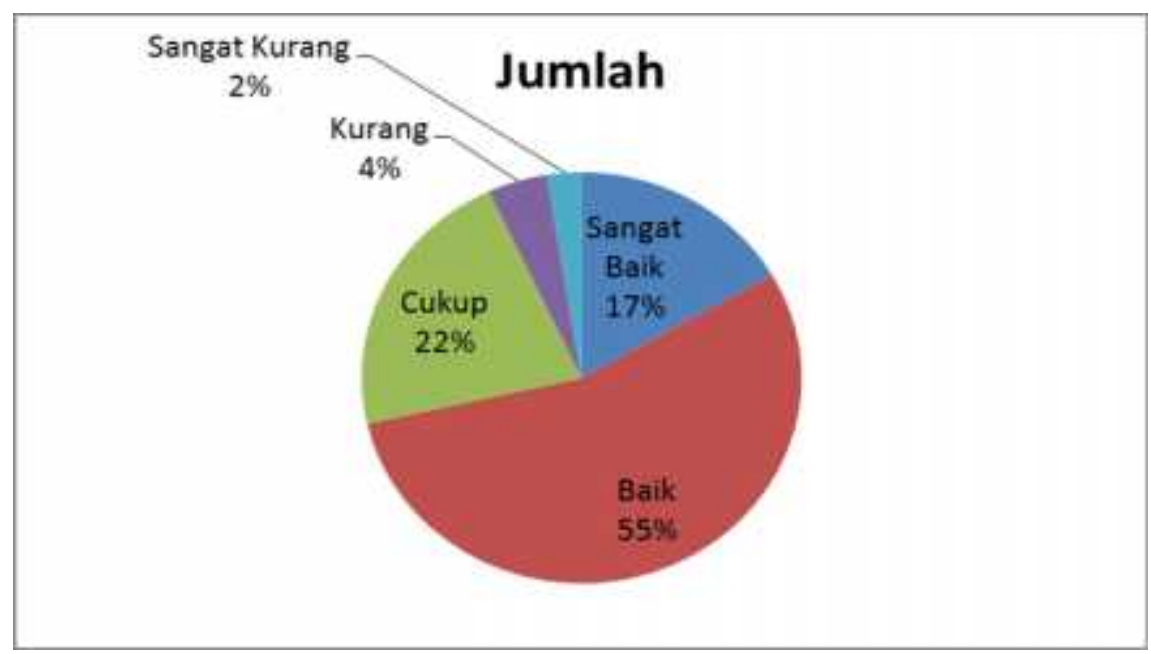

Gambar 1. Grafik Persentase kompetensi seorang Kristen yang dewasa

Dari penilaian beberapa aspek yang masih perlu ditingkatkan antara lain: Ketepatan waktu dalam mengawali dan mengakhiri pembelajaran masih mencapai $72 \%$ kategori baik dan sangat baik; Kemampuan menyelesaikan semua tugas administratif dan non-pembelajaran dengan tepat waktu sesuai standar yang ditetapkan masih mencapai $60 \%$ kategori baik dan sangat baik; Pemanfaatkan waktu luang selain mengajar untuk kegiatan yang produktif terkait dengan tugasnya; masih mencapai 67\% kategori baik dan sangat baik; Evaluasi diri secara spesifik, lengkap, dan didukung dengan contoh pengalaman diri sendiri masih mencapai $66 \%$ kategori baik dan sangat baik; Inisiatif untuk memperoleh masukan dari peserta didik tentang kegiatan pembelajaran (Misalnya, apakah yang dipelajari menarik, bermanfaat bagi peserta didik, sesuai dengan kebutuhannya) masih mencapai $72 \%$ kategori baik dan sangat baik; Pendokumentasian refleksi diri, misalnya dalam jurnal pembelajaran,catatan penting dalam RPP masih mencapai $40 \%$ kategori baik dan sangat baik. Hal ini menunjukkan sangat kurangnya perefleksian dalam diri mahasiswa; Pemanfaatan bukti gambaran kinerjanya untuk mengembangkan perencanaan dan pelaksanaan pembelajaran selanjutnya dalam program Pengembangan Keprofesian Berkelanjutan (PKB) masih mencapai 67\% kategori baik dan sangat baik; Keinginan membagi pengalamannya dengan kolega atau teman sejawat, termasuk mengundang mereka untuk mengobservasi cara mengajarnya dan memberikan masukan masih mencapai 55\% kategori baik dan sangat baik.

\section{Guru Bidang Studi Matematika Kristen}

Dilihat dari hasil penelitian menggambarkan bahwa sebanyak $75 \%$ lulusan tergolong dalam kategori sangat baik dan baik dalam bidang ini. Hal ini menunjukkan Lulusan pendidikan matematika Teacher College dalam kompetensi ini kuat, artinya sudah menyadari perannya sebagai pelayan Kristus didunia, memiliki wawasan dan pengetahuan yang luas dalam bidang studi matematika berdasarkan perspektif Kristen, memiliki sikap dan tindakan yang semakin menyerupai Kristus, serta menolong siswa-siswa bertumbuh dalam pengetahuan, keterampilan, sikap dan karakter mereka yang sesuai dengan pandangan hidup Kristen, meskipun belum termasuk secara keseluruhan. Pendapat pengguna digambarkan dalam diagram berikut: 


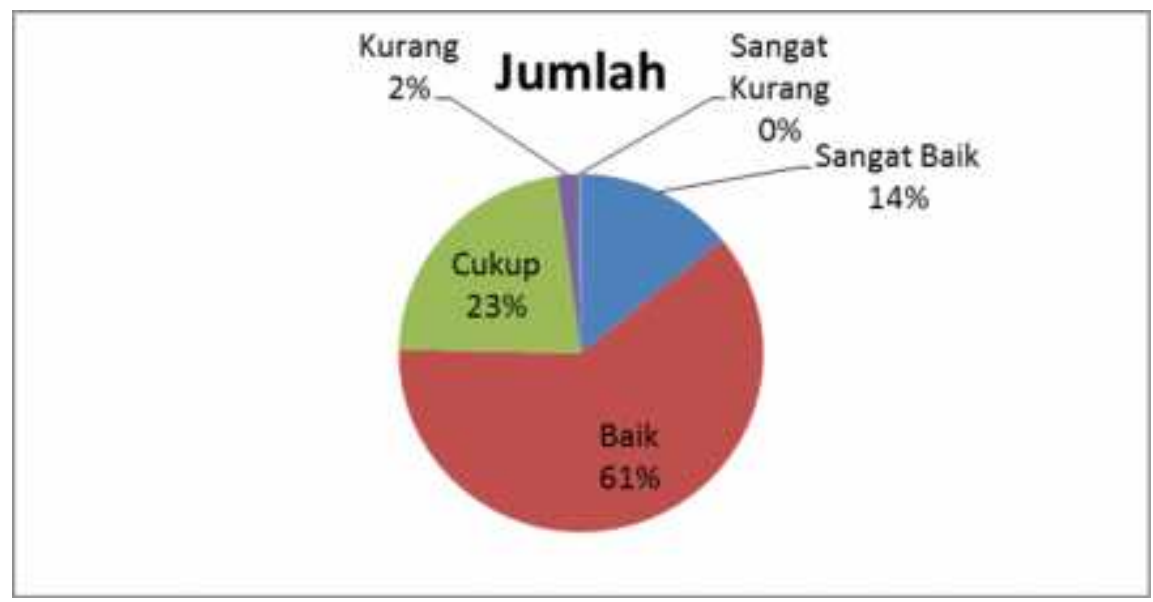

Gambar 2. Grafik Persentase guru bidang studi matematika kristen

Jika dilihat dari setiap aspek nya penilaiannya, secara umum lulusan Pendidikan matematika Teachers College masih kurang dibidang "kemampuan mengidentifikasi penyebab penyimpangan perilaku peserta didik untuk mencegah agar perilaku tersebut tidak merugikan peserta didik lainnya" yaitu sebesar $69 \%$ termasuk kategori baik dan sangat baik serta di bidang "mengaitkan setiap materi pembelajaran yang disampaikan kepada peserta didik dengan kehidupan sehari-hari dan menelaahnya berdasarkan kajian perspektif Kristen yang masih 57\% termasuk kategori baik dan sangat baik". Perlu perbaikan dalam kedua aspek ini. Agar alumni bisa mencapai indikator pencapaian tersebut maka sangat perlu ditanamkan selama perkuliahan. Hal ini bisa sebagai bahan masukan dalam proses mendidik mahasiswa pendidikan matematika Teachers College kedepan.

\section{Guru Bidang Studi Matematika Dengan Standar Internasional}

Dari hasil yang didapatkan sebesar $77 \%$ lulusan dikategorikan baik dan sangat baik dalam hal ini. Hal ini berarti secara garis besar lulusan pendidikan matematika Teachers College dalam kompetensi ini kuat, artinya secara umum memiliki pemahaman tentang peserta didik dalam berpikir, bertumbuh dan belajar; Menguasai dan memiliki kepekaan terhadap karakteristik peserta didik dalam aspek spiritual, emosional, sosial, intelektual dan fisik; Mengembangkan kurikulum berdasarkan prinsip-prinsip Alkitabiah; Menguasai teori belajar dan prinsip pendidikan serta menguasai standar kompetensi dan kompetensi dasar mata pelajaran yang diampu.

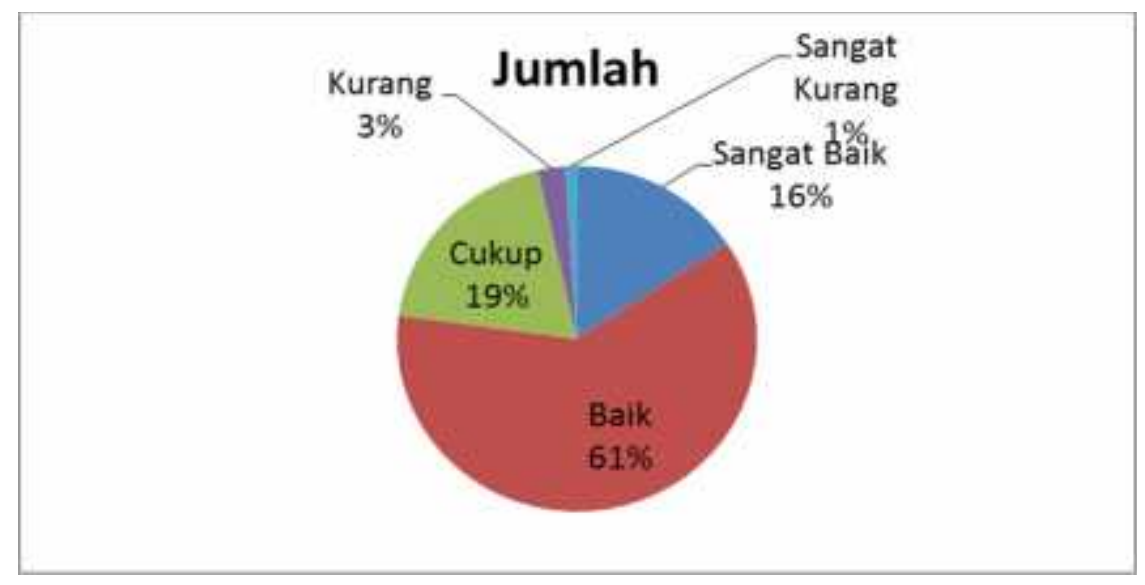

Gambar 3. Grafik Persentasi guru bidang studi matematika dengan standar internasional 
Setelah dilihat dari setiap indikator penilaian yang diberikan, masih terdapat hal-hal yang perlu diperbaiki dalam lulusan antara lain: Penggunaan berbagai metode dan teknik belajar untuk memotiviasi kemauan belajar peserta didik yang masih mencapai $67 \%$ kategori baik dan sangat baik; Kemampuan menyelesaikan semua tugas administratif dan nonpembelajaran dengan tepat waktu sesuai standar yang ditetapkan masih mencapai 56\% yang termasuk kategori baik dan sangat baik; Penggunaan media (alat bantu) mengajar, dan atau media audio-visual (termasuk TIK) untuk meningkatkan motivasi belajar peserta didik dalam mencapai tujuan pembelajaran masih mencapai $72 \%$ kategori baik dan sangat baik; Kemampuan menganalisa tingkat kemajuan peserta didik berdasarkan penilaian yang dilaksanakan masih mencapai $72 \%$ kategori baik dan sangat baik; Kemampuan mengidentifikasi dengan benar tentang bakat, minat, potensi, dan kesulitan belajar masing-masing peserta didik masih mencapai $62 \%$ kategori baik dan sangat baik; Pemberian kesempatan belajar kepada peserta didik sesuai dengan cara belajarnya masing-masing masih mencapai $73 \%$ kategori baik dan sangat baik; Melakukan interaksi dan mendorong peserta didik untuk memahami informasi yang telah disampaikan oleh guru masih mencapai $72 \%$ kategori baik dan sangat baik; Penyusunan alat penilaian yang sesuai dengan tujuan pembelajaran untuk mencapai kompetensi seperti yang tertulis dalam RPP masih mencapai 72\% kategori baik dan sangat baik; Merencanakan variasi teknik dan jenis penilaian yang digunakan untuk mengukur pencapaian kompetensi masih mencapai $72 \%$ kategori baik dan sangat baik; Pemberian umpan balik (feedback) kepada peserta didik tentang hasil penilaian masih mencapai $72 \%$ kategori baik dan sangat baik; Kemampuan menganalisis hasil penilaian untuk mengidentifikasi topik atau kompetensi dasar yang sulit, sehingga diketahui kekuatan dan kelemahan masing-masing peserta didik untuk keperluan remedial dan pengayaan masih mencapai $70 \%$ kategori baik dan sangat baik; Pemberian materi tambahan atau remedial terhadap peserta didik yang masih kurang pemahamannya masih mencapai $74 \%$ kategori baik dan sangat baik; Memanfatkan hasil penilaian sebagai bahan penyusunan rancangan pembelajaran yang akan dilakukan selanjutnya masih mencapai $66 \%$ kategori baik dan sangat baik.

\section{Seorang Anggota Komunitas Yang Signifikan}

Secara keseluruhan kompetensi lulusan dalam hal ini kuat, artinya lulusan dapat digolongkan mampu membina relasi yang baik dengan masyarakat, beradaptasi di tempat bertugas di seluruh wilayah Republik Indonesia yang memiliki keragaman iman, sosial, dan budaya serta membangun komunitas berdasarkan anugerah, kedamaian, pengharapan, kasih. Hal ini dapat dilihat dari hasil yang penelitian yang menunjukkan ketercapaian $76 \%$ dalam kategori baik dan sangat baik.

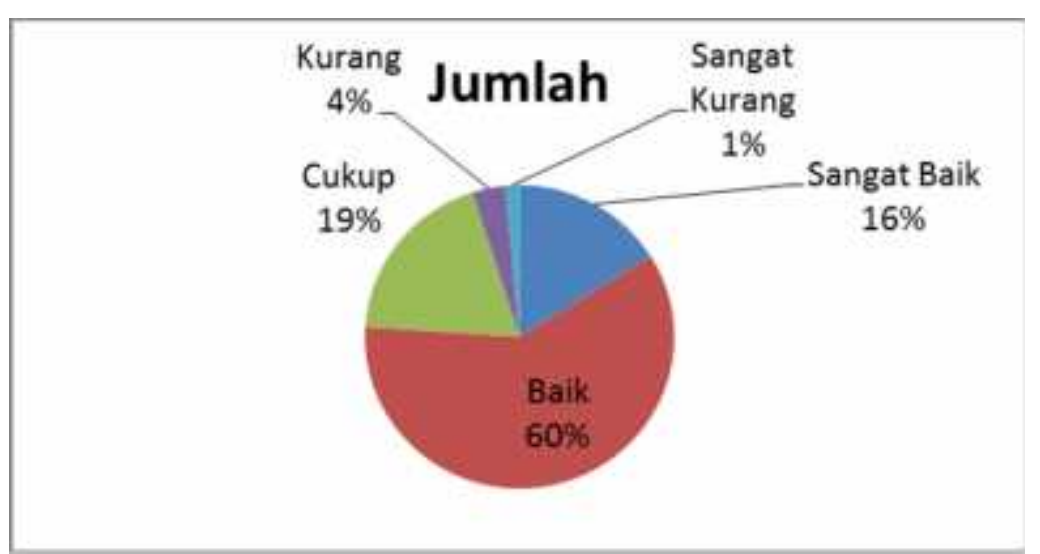

Gambar 4. Grafik Persentase seorang anggota komunitas yang signifikan 
Namun ada beberapa hal yang perlu diperbaiki dalam indikator pencapaian antara lain: Pelaksanaan penelitian, mengembangkan karya inovasi, mengikuti kegiatan ilmiah (misalnya seminar atau konferensi), serta aktif dalam melaksanakan pengabdian kepada masyarakat masih mencapai $48 \%$ kategori baik dan sangat baik; Peran aktif dalam kegiatan di luar pembelajaran yang diselenggarakan oleh sekolah dan masyarakat masih mencapai 67\% kategori baik dan sangat baik; Mampu berkomunikasi dengan masyarakat sekitar serta berperan dalam kegiatan sosial di masyarakat masih mencapai 68\% kategori baik dan sangat baik; Berkontribusi terhadap pengembangan sekolah dan mempunyai prestasi yang berdampak positif terhadap nama baik sekolah masih mencapai 68\% kategori baik dan sangat baik; Memiliki wawasan yang luas seputar permasalahan sosial melalui update informasi terkini di media cetak dan elektronika, serta mampu mengajak peserta didik untuk berpartisipasi secara aktif di dalamnya masih mencapai $73 \%$ kategori baik dan sangat baik;

\section{Pembahasan}

Didasarkan pada Teachers College Student Handbook 2015/2016, maka hasil penelitian yang telah dilakukan diperoleh beberapa hal yang perlu diperhatikan untuk perbaikan terhadap kompetensi guru pendidikan matematika Teachers College antara lain: (1) Mengaitkan setiap materi pembelajaran yang disampaikan kepada peserta didik dengan kehidupan sehari-hari dan menelaahnya berdasarkan kajian perspektif Kristen, (2) Pendokumentasian refleksi diri, misalnya dalam jurnal pembelajaran, catatan penting dalam RPP, (3) Keinginan membagi pengalamannya dengan kolega atau teman sejawat, termasuk mengundang mereka untuk mengobservasi cara mengajarnya dan memberikan masukan, (4) Pelaksanaan penelitian, mengembangkan karya inovasi, mengikuti kegiatan ilmiah (misalnya seminar atau konferensi), serta aktif dalam melaksanakan pengabdian kepada masyarakat.

Berkaitan dengan kurangnya kompetensi mahasiswa dalam beberapa bidang, hal tersebut bisa diakibatkan karena minimnya pengembangannya semasa kuliah di jurusan Pendidikan Matematika Teachers College. Untuk itu perlu usaha perbaikan terhadap mahasiswa antara lain: (1) Dalam perkuliahan menekankan kaitan setiap materi pembelajaran yang disampaikan kepada peserta didik dengan kehidupan sehari-hari dan menelaahnya berdasarkan kajian perspektif Kristen, (2) Mendorong mahasiswa untuk mendokumentasikan refleksi diri, misalnya dalam jurnal pembelajaran, catatan penting dalam RPP, (3) Mendorong mahasiswa untuk membagi pengalamannya dengan kolega atau teman sejawat, termasuk memberi kesempatan untuk mereka memberi masukan dan penilaian cara mengajar/ belajar dan memberikan masukan, (4) Mendorong dan membimbing mahasiswa dalam pelaksanaan penelitian, mengembangkan karya inovasi, mengikuti kegiatan ilmiah (misalnya seminar atau konferensi), serta aktif dalam melaksanakan pengabdian kepada masyarakat lewat penekanan tugas-tugas, serta membimbing mereka lebih banyak.

\section{SIMPULAN}

Dari hasil penelitian diperoleh kesimpulan:

1. Secara umum alumni pendidikan matematika Teachers College berdasarkan pengguna lulusan sudah mencapai keempat kompetensi berdasarkan graduate profile Teachers College , antara lain: Guru bidang studi matematika Kristen, Guru bidang studi matematika dengan standar internasional, Seorang Kristen yang dewasa, Seorang anggota komunitas yang signifikan.

2. Jika dilihat berdasarkan pernyataan yang diturunkan dari indikator kompetensi, beberapa hal yang perlu ditingkatkan kompetensi lulusan antara lain: (1) Mengaitkan setiap materi 
pembelajaran yang disampaikan kepada peserta didik dengan kehidupan sehari-hari dan menelaahnya berdasarkan kajian perspektif Kristen, (2) Pendokumentasian refleksi diri, misalnya dalam jurnal pembelajaran, catatan penting dalam RPP, (3) Keinginan membagi pengalamannya dengan kolega atau teman sejawat, termasuk mengundang mereka untuk mengobservasi cara mengajarnya dan memberikan masukan, (4) Pelaksanaan penelitian, mengembangkan karya inovasi, mengikuti kegiatan ilmiah (misalnya seminar atau konferensi), serta aktif dalam melaksanakan pengabdian kepada masyarakat.

3. Berkaitan dengan kurangnya kompetensi mahasiswa dalam beberapa bidang, hal tersebut bisa diakibatkan karena minimnya pengembangannya semasa kuliah di jurusan Pendidikan Matematika Teachers College. Untuk itu perlu usaha perbaikan terhadap mahasiswa antara lain: (1) Dalam perkuliahan menekankan kaitan setiap materi pembelajaran yang disampaikan kepada peserta didik dengan kehidupan sehari-hari dan menelaahnya berdasarkan kajian perspektif Kristen, (2) Mendorong mahasiswa untuk mendokumentasikan refleksi diri, misalnya dalam jurnal pembelajaran, catatan penting dalam RPP, (3) Mendorong mahasiswa untuk membagi pengalamannya dengan kolega atau teman sejawat, termasuk memberi kesempatan untuk mereka memberi masukan dan penilaian cara mengajar/ belajar dan memberikan masukan, (4) Mendorong dan membimbing mahasiswa dalam pelaksanaan penelitian, mengembangkan karya inovasi, mengikuti kegiatan ilmiah (misalnya seminar atau konferensi), serta aktif dalam melaksanakan pengabdian kepada masyarakat lewat penekanan tugas-tugas, serta membimbing mereka lebih banyak.

\section{UCAPAN TERIMA KASIH}

Penelitian ini didukung oleh Universitas Pelita Harapan lewat skema penelitian Fakultas Ilmu Pendidikan Tahun Ajaran 2015-2016 No. 0453/TC-FIP-UPH/III/2015.

\section{DAFTAR PUSTAKA}

Alma, Buchari. 2009. Pengantar Statistika untuk Penelitian Pendidikan, Sosial, Ekonomi, Komunikasi, dan Bisnis. Bandung: Alfabeta

Arikunto, Suharsimi. 2010. Prosedur Penelitian suatu pendekatan praktik. Jakarta: Rineka cipta.

College, Teachers. 2015. Student Handbook 2015/2016: Universitas Pelita Harapan.

Peraturan Pemerintah Republik Indonesia Nomor 32 Tahun 2013 tentang Perubahan Atas Aturan Pemerintah Nomor 19 Tahun 2005 tentang Standar Pendidikan Nasional.

Undang-Undang Republik Indonesia Nomor 20 Tahun 2003 tentang Sistem Pendidikan Nasional.

Sanjaya, Wina. 2006. Strategi Pembelajaran. Jakarta: Kencana.

Van Brummelen, H. 2009. Berjalan dengan Tuhan di dalam kelas: Pendekatan Kristiani untuk pembelajaran. Jakarta: Universitas Pelita Harapan. 